\title{
Approach-related morbidity in transthoracic anterior spine surgery: a clinical study and review of literature
}

\author{
Morbidade relacionada à abordagem transtorácica anterior da \\ coluna: estudo clínico e revisão da literatura \\ Morbilidad relacionada con el abordaje torácico anterior de la \\ columna: estudio clínico y revisión de la literatura
}

\author{
Juliane Zenner ${ }^{2}$ \\ Heiko Koller ${ }^{1,2}$ \\ Axel Hempfing ${ }^{2}$ \\ Jörg Hutter ${ }^{3}$ \\ Wolfgang Hitzl ${ }^{4}$ \\ Herbert Resch ${ }^{1}$ \\ Mark Tauber ${ }^{1}$ \\ Oliver Meier ${ }^{2}$ \\ Luis Ferraris ${ }^{2}$
}

\begin{abstract}
Background: Anterior access to the thoracic spine is done by open thoracotomy (OTC) or video-assisted thoracoscopic surgery (VATS). VATS is known as the method which results in lower morbidity rates, but there is little evidence of its less invasiveness. Objective: The current study yielded for outcome data concerning patients' perception of approachrelated morbidity (ArM) following OTC for spinal surgery and that of a control group having a chest tube thoracotomy (CTT). Methods: We performed a questionnaire assessment of ArM after OTC and CTT. Applying strict inclusion criteria, we compared outcomes in terms of percentage morbidity (Morbidity \%) of 43 patients that underwent OTC for instrumented scoliosis correction to 30 patients that had CTT for
\end{abstract}

\section{RESUMO}

Introdução: A abordagem anterior da coluna torácica tem sido utilizada por meio da toracotomia aberta (TA) ou vídeo-assistida (TVA). A abordagem vídeo-assistida tem sido mencionada como a de menor morbidade do procedimento, apesar de não existir evidência científica que confirme essa observação. Objetivo: Observar os resultados relacionados à morbidade da toracotomia aberta para a correção de deformidade da coluna vertebral e toracotomia para a colocação de tubo de drenagem torácica, utilizando um grupo de pacientes como controle. Métodos: Com base em questionário relacionado com a avaliação da morbidade da abordagem anterior da coluna torácica respondido pelos pacientes, e utilizando critérios estritos de inclusão dos pacientes, foram avaliados, em termos de porcentagem

\section{RESUMEN}

Introducción: el abordaje anterior de la columna torácica ha sido utilizado por medio de la toracotomía abierta o vídeo asistida. El abordaje video asistida ha sido mencionada como la menor morbilidad del procedimiento, a pesar de existir poca evidencia científica confirmando esa observación. Objetivo: el objetivo del presente estudio fue observar los resultados relacionados con la morbilidad de la toracotomía abierta para la corrección de la deformidad de la columna vertebral y toracotomía para la colocación de tubo de drenaje torácica, utilizando ese grupo como Control. Métodos: con base en un cuestionario respondido por los pacientes; $y$ relacionado con la evaluación de la morbilidad del abordaje anterior de la columna torácica y utilizando criterios estrictos de inclusión de los pa-

\footnotetext{
Study carried out at Department for Traumatology and Sports Medicine, Paracelsus Medical University Salzburg, Austria

'MD; Department for Traumatology and Sports Medicine, Paracelsus Medical University Salzburg, Austria.

${ }^{2}$ MD; German Scoliosis Center, Werner Wicker Clinic, Bad Wildungen, Germany.

${ }^{3} \mathrm{MD}$; Department for General Surgery, Paracelsus Medical University Salzburg, Austria.

${ }^{4}$ PhD; Mhc; Research Office, Biostatistics, Paracelsus Medical University Salzburg, Austria. 
minor thoracic pathologies (e.g., pneumothorax). Results: Mean age in CTT and OTC Group was 50.2 and 16.5 years old, follow-up was of 32.2 and 58.4 months, and mean incision length was 2.5 and 25.5 $\mathrm{cm}$, respectively. Mean number of levels fused in the OTC Group was 5.8. Mean morbidity ( $0 \%$ delineating no cases, $100 \%$ delineating highest morbidity) for the CTT Group was $10.8 \pm 15.4 \% \quad(0-59.5 \%), \quad 42 \%$ of patients had no morbidity. Signs of intercostal neuralgia (ICN) were present in $16.7 \%$. A total of $35.5 \%$ had a morbidity $>10 \%$ (mean: $27.5 \%$ ), and $10 \%$ of morbidity cases were defined as having a chronic post-thoracotomy pain (CPP). In the OTC Group, mean morbidity was $7.0 \pm 12.7 \%$ (0-52.1\%), 44\% had no morbidity. Out of the sample, $18.6 \%$ had morbidity $>10 \%$ (mean: $28.6 \%$ ). Signs of ICN were present in $14 \%$. In both groups, the presence of ICN had a significant impact on and showed correlation with morbidity $(p<0.0001)$. In terms of clinical judgement, the severity of the ArM after a CTT or OTC was generally mild except for one patient in each group. Age and follow-up were significantly different between groups $(p<0.0001$, $p=0.02$ ), but the intergroup difference in morbidity was not significant $(p=0.08)$. Conclusions: ArM after open thoracic spinal surgery or VATS procedures can be assessed using the questionnaire. To put ArM of OTC into perspective, a Control Group with simple CTT was selected, demonstrating that morbidity was not different between the OTC and CTT groups. Patients with increased signs of ICN do worse which was reflected by increased morbidity in both groups. The study demonstrates that not only the cosmesis is not a concern for patients undergoing OTC, but neither is the ArM a concern, equalling that of a simple CTT. (morbidade \%), 43 pacientes submetidos à toracotomia aberta para tratamento da escoliose (Grupo OTC) e 30 pacientes portadores de outras doenças de menor gravidade submetidos à toracotomia para a colocação de dreno de tórax após o procedimento (por exemplo, pneumotórax) (Grupo CTT). Resultados: A média de idade dos pacientes de ambos os grupos foi 50,2 e 16,5 anos; seguimento clínico médio foi de 32,2 e 58,4 meses; e a extensão da incisão da pele 2,5 e $25,5 \mathrm{~cm}$, respectivamente. A média do número de vértebras artrodesadas foi 5,8 no grupo submetido à toracotomia aberta para a correção de deformidade. A morbidade média (variando de $0 \%$, nenhuma morbidade, a $100 \%$, alta morbidade) no grupo de pacientes submetidos à toracotomia para colocação de dreno de tórax foi $10,8 \pm 15,4(0-59,5 \%)$, e $42 \%$ dos pacientes não apresentavam morbidade. No grupo submetido à toracotomia aberta para a colocação do dreno de tórax, foi observada neuralgia intercostal em 16,7\%, e $35,5 \%$ dos pacientes apresentavam morbidade maior que $10 \%$ (média 27,5\%). A morbidade foi definida como a presença de dor crônica após toracotomia. No grupo submetido à toracotomia aberta para tratamento de escoliose, a média da morbidade foi $7,0 \pm 12,7 \%(0-52,1 \%)$, e $44 \%$ não apresentava morbidade. De toda a amostra, 18,6\% apresentaram morbidade $>10 \%$ (média: $28,6 \%$ ). Sinais de neuralgia intercostal foram observados em 14\% dos pacientes. Em ambos os grupos, a presença de neuralgia intercostal teve impacto significativo e apresentou correlação com a morbidade $(p<0,0001)$. Na avaliação clínica, a gravidade da morbidade após a toracotomia aberta para a correção da deformidade vertebral ou toracotomia para a colocação de dreno torácico foi de grau leve, com exceção de um paciente em cada grupo. A idade e o tempo de seguimento foram diferentes entre os dois grupos $(\mathrm{p}<0,0001$, $p=0,02$ ), mas não foi observada diferença no índice de morbidade entre os dois grupos $(p=0,08)$. Conclusões: cientes, fueron evaluados 43 pacientes sometidos a toracotomía abierta para tratamiento de la escoliosis; y 30 pacientes portadores de otras enfermedades de menor gravedad, que fueron sometidos a la toracotomía para la colocación de dreno de tórax después del procedimiento. Resultados: el promedio de edad de los pacientes sometidos al procedimiento en el tórax y a la toracotomía para la colocación de dreno o toracotomía abierta para tratamiento de escoliosis fue, respectivamente: 50.2 años $y$ 16.5 años; el seguimiento clínico fue de 32.2 meses y 54.8 meses; y la extensión de la incisión de la piel 2.5 $\mathrm{cm}$ y $25 \mathrm{~cm}$. El promedio del número de vértebras artrosadas fue 5.8 en el grupo sometido a la toracotomía abierta para la corrección de deformidad. La morbilidad promedio (variando de $0 \%$ - ninguna morbilidad a $100 \%$ - alta morbilidad) en el grupo de pacientes sometidos a la toracotomía para colocación de dreno de tórax fue de $10.8 \pm 15.4$ (0-59.5\%), y un $42 \%$ de los pacientes no presentaron morbilidad. En el grupo sometido a la toracotomía abierta para la colocación del dreno de tórax fue observada neuralgia intercostal en 16.7\%, y 35\% de los pacientes presentaron morbilidad mayor que 10\% (pormedio de un 27.5\%). La morbilidad fue definida como la presencia de dolor crónico después de la toracotomía. En el grupo sometido a la toracotomía abierta para tratamiento de escoliosis el promedio de la morbilidad fue $7.0 \pm 12.7 \%(0-52.1 \%)$, y $44 \%$ no presentaron morbilidad. Señales de neuralgia intercostal fueron observados en 14\% de los pacientes. En ambos grupos la presencia de neuralgia intercostal tuvo impacto significativo y presentó correlación con la morbilidad $(p<0.0001)$. En la evaluación clínica, la gravedad de la morbilidad después de la toracotomía abierta para la corrección de la deformidad vertebral o toracotomía para la colocación de dreno torácico fue de grado leve, con excepción de un paciente en cada grupo. La edad y el tiempo de seguimiento fueron diferentes en- 
A morbidade da toracotomia aberta ou vídeo-assistida pode ser avaliada por meio de questionários respondidos pelos pacientes. A avaliação da morbidade após a realização de toracotomia aberta para a correção de deformidade da coluna vertebral não apresentou diferença em relação à morbidade observada nos pacientes nos quais foi realizada a toracotomia para a colocação de dreno torácico. Os pacientes com neuralgia intercostal apresentaram o maior índice de morbidade em ambos os grupos. Os resultados do estudo demonstraram que o aspecto cosmético não foi relevante para os pacientes submetidos à toracotomia aberta e o índice de morbidade foi semelhante no grupo de pacientes submetidos à toracotomia aberta e toracotomia para a colocação de dreno de tórax. tre los dos grupos $(p<0.0001)$, pero no fue observada diferencia entre el indice de morbilidad entre los dos grupos ( $p=0.08)$. Concluciones: la morbilidad de la toracotomía abierta o video asistida puede ser evaluada por medio de cuestionarios respondidos por los pacientes. La evaluación de la morbilidad después de la realización de toracotomía abierta para la corrección de deformidad de la columna vertebral no presentó diferencia con la morbilidad observada en los pacientes en que fue realizada la toracotomía para la colocación de dreno torácico. Los pacientes con neuralgia intercostal presentaron el mayor índice de morbilidad en ambos los grupos. Los resultados del estudio demostraron que el aspecto cosmético no fue relevante para los pacientes sometidos a la toracotomia abierta; y el índice de morbilidad fue semejante en el grupo de pacientes sometidos a la toracotomía abierta y toracotomía para la colocación de dreno de tórax.
KEYWORDS: Morbidity; Spine/ surgery; Thoracotomy/ methods; Video-assisted surgery/methods

\author{
DESCRITORES: Morbidade; \\ Coluna vertebral/cirurgia; \\ Toracotomia/métodos; \\ cirurgia vídeo-assistida/ \\ métodos
} métodos
DESCRIPTORES: Morbilidad; Columna vertebral/cirugía; Toracotomía/métodos;
Cirugía asistida por video/ Toracotomía/métodos;
Cirugía asistida por video/

\section{INTRODUCTION}

Anterior access to the thoracic and thoracolumbar spine has traditionally been gained by open posterolateral thoracotomy (OTC) or a thoraco-abdominal transdiaphragmatic approach. The indications for anterior-only surgeries remain ${ }^{1-5}$, although the frequency of anterior releases in scoliosis surgeries decreased due to more effective posterior-only techniques and transpedicular correction syste$\mathrm{ms}^{2-7}$. With the anterior approach, some surgeons support the usage of video-assisted thoracoscopic surgery (VATS), e.g., for anterior correction in adolescent idiopathic scoliosis (AIS) $)^{4,7-10}$ or for the anterior decompression, fusion and instrumentation of thoracolumbar fractures ${ }^{11}$. Compared to using an OTC that is deemed to cause significant chest wall dissection, the usage of VATS is supposed to confer reduced perioperative and short-term morbidity in terms of less perioperative pain, better mid- and long-term pulmonary and shoulder-girdle function, faster recovery from surgery, better cosmesis and reduction of overall 'approach-related morbidity' $(\mathrm{ArM})^{12-27}$. However, while there is an increasing and albeit appodictive call for minimally invasive procedures in orthopaedic surgery, there is a lack of evidence concerning the invasiveness of an open thoracotomy and, vice versa, the less invasiveness and advantages of VATS in spinal surgery ${ }^{12}$. Coincidentally, one of the authors' institution is receiving a significant number of patients that present with failed spinal surgeries following VATS, including the sequels of pseudoarthrosis, construct failure and deformity, who have to be subjected to OTC and $360^{\circ}$ revision surgeries. Hence, the authors consider that the investigation of patients' self-rated mid- to longterm morbidity at the operated chest wall after an OTC for anterior spinal surgery is indicated.

Whether spinal surgery is conducted using an OTC or VATS, patients will perceive some kind of ArM at the chest wall. To assess the severity of this particular morbidity, a questionnaire seemed appropriate. With such questionnaire, one should be able to compare the results of, e.g., matched-pair cohorts undergoing OTC or VATS for the treatment of identical spinal pathologies. 
On the other hand, assessment of raw data of the ArM after OTC is valuable, enabling data pooling for the future and giving an objective insight. To put the morbidity of a major spinal open transthoracic surgery into perspective, one can compare it to the ArM of the smallest transthoracic surgery possible, i.e., the placement of a single chest tube via chest tube thoracotomy (CTT). Accordingly, the first purpose of the current study was to design a questionnaire that could assess the so called 'approach-related morbidity' of OTC in comparison to CTT. Second, the authors sought to yield first mid- and long-term outcome data in terms of self-rated chest wall morbidity using the proposed questionnaire in patients that underwent OTC for anterior scoliosis correction. Although the ArM that might go with a single CTT for minor thoracic pathologies is not a surrogate for the ArM that might be associated with VATS, the usage of our questionnaire in patients that underwent placement of a simple chest tube was selected to illustrate the severity of ArM with OTC.

The questionnaire may enable further comparisons of ArM that goes with OTC and VATS for spinal procedures. The current study yields for the assessment of raw data concerning ArM after OTC and CTT in light of a critical review of the available literature on the 'morbidity' of spinal surgeries using OTC or VATS.

\section{METHODS}

To compare the ArM after an OTC for anterior spinal deformity correction and a minithoracotomy for placement of a thoracic chest tube, the current study was conducted at the departments of trauma ${ }^{13}$ and general ${ }^{28}$ surgery of a university hospital and at a busy spine center ${ }^{14}$. For assess the morbidity, an easy-to-understand questionnaire (available from the authors) was designed. The questionnaire contains a total of 13 questions with the first 10 questions assessing the presence of pain or discomfort during various daily activities in the area of the operated chest wall. The severity of symptoms is assessed on a visual analogue scale (VAS) with anchor points of , 0 ' delineating no pain/ discomfort and ,10' delineating worst conceivable pain. The last 3 questions have adjective rating scales and evaluate the frequency of the experienced pain at the chest wall, the frequency of oral pain medication and the presence of any experienced numbness, tingling or similar discomfort at the wound area. Two different questions (question $\mathrm{A}$ and B) characterize the symptoms related to intercostal neuralgia (ICN). ICN can result from inadvertent injury of the intercostal nerves and we defined the presence of ICN by 'pain that is radiating, starts at the wound area and directs towards the middle of the chest'. In addition to the visual analogue and adjective rating scale, the questionnaire collected information on demographic, incision length and comorbidity variables, and (in case of any kind of pain or discomfort at the chest wall) patients were asked to locate the perceived pain on a front-back sketch of the human thorax to control for the pain being located at the incisional scar. The patients were also asked for global outco- me assessment of the transthoracic surgery. For statistical analysis, numerical orders for the description of global outcomes were used (excellent $=1$, good $=2$, moderate $=3$, poor $=4)$. In general, the questionnaire contains 13 questions used for calculation. According to the patients' marks ticked on the first 10 VAS-questions, a total of 100 points (pts) can be yielded. In the last 3 questions, each is assigned $0.0,2.5,7.5$ or $10 \mathrm{pts}$ yielding a possible maximum of 30 pts at worst. Overall, the summed points can be as high as 130 , delineating worse outcome at the chest wall related to the transthoracic approach. The individual result is expressed as shown below:

Morbidity $(\%)=\frac{\text { Summarized points }}{\text { Maximal possible points }} \times 100$

$100 \%$ morbidity delineates the worst conceivable morbidity and $0 \%$ delineates no morbidity.

For the purpose of shedding light on the mid- to long-term morbidity of OTC for anterior spinal surgery, the authors decided to investigate a consecutive series of 50 patients that showed up for clinical and radiographic follow-up at the outpatient clinic of the spine center $^{2}$. Minimum follow-up had to be of six months. Prior to clinical follow-up, the patients were invited to participate in the study and were briefly instructed into the anonymous questionnaire by a research nurse which collected the questionnaires afterwards. For inclusion in the study, the patients had to have undergone anterior-only instrumented correction for AIS or degenerative (De-Novo) adult scoliosis through OTC with or without lumbar extension. Patients were excluded if there was evidence of psychiatric illness demanding medical treatment, concomitant posterior surgery, any spinal surgery prior to the index procedure or if complications related to the spinal procedure other than related to the OTC were noted (e.g. pseudoarthrosis, implant failure, etc).

For the purpose of constructing a control group that could put the morbidity of an OTC into perspective and give an impression of the ArM following a small transthoracic surgical opening, the authors considered appropriate to choose patients submitted to single CTT with a short- to mid-term follow-up of at least two months. Medical charts of all patients that had a minithoracotomy and chest tube placement for various pulmonary and thoracic pathologies between 2004 and 2007 at the departments of trauma and general surgery at the university hospital ${ }^{13,28}$ were reviewed. Patients were included if they met the following criteria: single CTT, spontaneous, traumatic or iatrogenic pneumothorax, single or serial rib fractures with concomitant haemato or haemato-pneumothorax and any serothorax indicating CTT. Patients were excluded if they had ipsilateral injuries to the shouldergirdle or abdomen, spinal injuries, prior spinal, transthoracic or abdominal surgery, a history of thoracic back pain or a documented neoplastic disease. 
The presence of chronic post-thoracotomy pain (CPP) was defined as "pain that recurred or persists along a thoracotomy incision at least two months following the surgical procedure ${ }^{29}$. Because no grading of the severity of CPP exists and no threshold has been set, delineating when CPP becomes clinically significant, we defined the presence of $\mathrm{CPP}$ if the morbidity was $>10 \%$ resembling a rather strong cut-off.

Technique of conventional posterolateral thoracotomy and thoraco-abdominal transdiaphragmatic approach In the authors' institution ${ }^{14}$, patients are placed in lateral decubitus position with the convexity of the curve up. The operating table is angulated under the apex of the curvature to allow more room for the surgical procedure. The skin incision is slightly curved from the paraspinous area to the chondrocostal junction over the rib to be resected. Which rib is to be excised depends on the localization of the curvature and the orientation of the rib (horizontally or sloping). Each muscle layer is divided with electrocautery and marking sutures are made. The periosteum of the rib is exposed and incised with electrocautery, further dissected with a raspartorium and subperiostally stripped with a curved-tip rib elevator. The rib is osteotomized with a rib cutter as far posteriorly as necessary (approximately $4 \mathrm{~cm}$ anterior to the tip of the transverse process) and anteriorly within the costochondral junction. The remaining cartilage is then transected into two parts with a knife. The thorax is then opened by incision of the rib bed and the lung is deflated and anteriorly retracted using moist lap pads. For the thoraco-abdominal approach, the skin incision is extended down to the abdomen. The peritoneum under the costochondral cartilage is mobilized and the abdominal muscles divided separately. The diaphragm is peripherally transected by electrocautery approximately $15 \mathrm{~mm}$ from the costal insertion. A Zielke chest spreader $^{\circledR}$ is inserted with moist abdominal pads underneath for soft tissue protection. The parietal pleura is superiorly and distally incised and mobilized to reach the anterior part of the spine. For lumbar approach, the psoas muscle is dissected from the spine and posteriorly retracted. The segmental vessels are dissected and ligated at the midvertebral body level. A moist abdominal pad is inserted anteriorly between the spine and the great vessels. Afterwards, disc excision and instrumentation is performed. Wound closure is performed with a doubled suture of the pleura, insertion of a chest tube (and two retroperitoneal drains in case of a thoracoabdominal approach) and doubled sutures of each muscle layer after reconstruction of the costochondral cartilage. The superior and inferior ribs are approximated by two non-resorbable sutures to achieve a uniform intercostal rib space. The chest tube is sutured in place and the wound suture is closed.

\section{Technique for minithoracotomy}

CTT is performed in compliance with standard methods in the trauma institution (Figure 1). Following infiltration
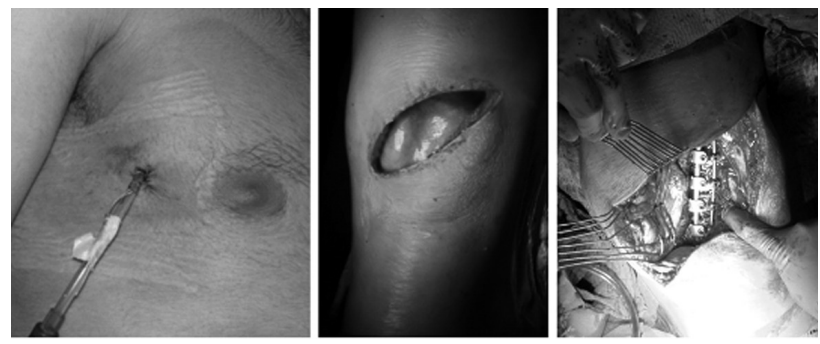

Figure 1

(A) Illustration of approach-related morbidity following chest tube thoracotomy. Location and size of CTT day 5. (B and C) Illustration of approach-related incision and intraoperative exploration with thoracotomy for anterior instrumented scoliosis correction T4-LT.

of the incision site and rib periosteum using a long-lasting local anaesthetic, the skin incision is $2-3 \mathrm{~cm}$ in length and about $1 \mathrm{~cm}$ below the $5^{\text {th }}$ or $6^{\text {th }}$ intercostal space, and centered sligthly anterior to the mid-axillary line. The subcutaneous tissue is bluntly dissected to the top of the $6^{\text {th }}$ or $7^{\text {th }}$ rib using a scissor. The pleura is bluntly punctured with the tip of a clamp and the surgeon's index finger controls for pleural adhesions and assures that intrathoracic extrapulmonary access was accomplished. A Korn-tongue connected to the tip of the chest tube is advanced into the pleural space directing posterior and downward or posterior and upward the thoracic cavity whether a haemato/serothorax or pneumothorax is present. The procedure is closed by suturing the chest tube in place and skin sutures.

\section{Statistical analysis}

Pearson's $\chi^{2}$ test and Fisher's Exact test was used to analyze cross-tabulation tables. Correlation analyses were done by means of Pearson's and Spearman's correlation coefficient. A two-factorial ANOVA with post-hoc tests were used to analyze data. A p-value less than $5 \%$ was considered statistically significant. All computations and illustrations were done with Statistic 6.1 (StatSoft, Tulsa, OK). Statistical analysis was done by one of the authors (W.H.).

\section{RESULTS}

\section{OTC Group}

A total of 45 out of 50 consecutive patients that presented for clinical and radiological follow-up after anterior transthoracic scoliosis correction between July and December 2007 took part in the study and answered to the questionnaires. Five patients were found to have subsequent posterior fusion following anterior releases, thus being excluded, one patient was excluded because of an incomplete questionnaire and another patient had a symptomatic spondylolisthesis below a lumbar fusion level. In general, 43 patients had complete questionnaires, and patients' charts and follow-up data indicated no complication related to the instrumented anterior scoliosis surgery. Mean age of the patients was $16.5 \pm 10.4$ years (range, 11-57y) at index surgery and 20.6 \pm 10.9 years (range, $14-58 \mathrm{y}$ ) at 
follow-up. The study sample comprised 40 females (93\%) and 3 males (7\%). Follow-up was $58.4 \pm 70.9$ months on average (range, 9-33.7 months). Single OTC was performed in 25 patients $(58.1 \%)$ and a thoraco-abdominal transdiaphragmatic approach in 18 patients $(41.9 \%)$. Mean number of levels fused was 5.8 \pm 1.5 (range, $3-8$ ). Out of all patients, $10(23.3 \%)$ had an academic educational level or were still at university, and 33 patients $(76.7 \%)$ had a nonacademic educational level or were still attending school. Mean incision length in the scoliosis patients was 25.5 \pm 3.2 $\mathrm{cm}$ (range, 20-36 cm). Self-rated global outcome with the transthoracic scoliosis surgery average was $1.2 \pm 0.4$ (range, 1-2). Thirty-three patients (76.7\%) noted an excellent outcome and 10 patients $(23.3 \%)$ noted a good outcome. In the 43 patients treated with OTC for instrumented anterior-only scoliosis correction using the further developed ventral Zielke's derotation technique, the morbidity was $7.0 \pm 12.7 \%$ on average (range, $0-52.1 \%)^{30}$. Nineteen patients $(44.2 \%)$ had no morbidity related to their open transthoracic surgery ( $0-1 \%$ morbidity). A total of $55.8 \%$ of the patients noted slight to moderate discomfort or pain related to the thoracic wound. Eight patients $(18.6 \%)$ had a morbidity greater than $10 \%$ (mean: $28.6 \pm 16.6 \%$; range 13 $52.1 \%$ ), which we defined as having CPP. Out of these eight patients, five judged their clinical outcome as excellent and three as good. Except for two patients, the pain and discomfort perceived at the chest wall was not a distracting or significant problem during daily activities. In contrast, 35 patients $(81.4 \%)$ had a morbidity equal to or less than $10 \%$ (mean $2.1 \pm 2.5 \%$, range $0-7.8 \%$ ).

In general, 20 patients that had at least $>1 \%$ morbidity made notes on the character and localization of pain. All these patients who noted remaining pain at the chest wall made marks at the appropriate chest wall site on the antero-posterior sketch of the thoracic cage. Signs of ICN were present in 6 patients $(14 \%)$.

\section{CTT Group}

A consecutive series of 251 patients that had received CTT for chest tube placement between 2004 and 2007 were indentified in surgical registries. Largely due to neoplastic disease, polytrauma, second stage thoracic surgery or trauma associated with the spine, abdomen or shoulder-girdle, only 55 patients met inclusion criteria. Fifty patients could be tracked successfully. Out of these, 6 patients had died, 10 were living abroad and another 4 did not respond. Overall, 30 patients had complete follow-up after CTT and participated in the study, resulting in a follow-up rate of $54.5 \%$. Fifteen patients $(50 \%)$ had been treated at the department of general surgery for non-traumatic benign intrathoracic pathologies and $15(50 \%)$ at the department of trauma surgery for thoracic and chest-wallrelated trauma. Mean age of the patients was $50.2 \pm 16$ years (range, 15-71 years old) at the time of CTT and $52.5 \pm 16$ years (range, 19-73 years old) at follow-up. The study sample comprised 6 females (19.4\%) and 24 males (80\%). Follow-up was of 32.2 \pm 18.4 months (range, 2-78 months). No patient had recurrent thoracic or chest-wall-related trauma, recurrent thoracic disease or surgery until follow-up. Out of 20 patients that were employed and made notes on work status, $5(25 \%)$ had academic level of education and 15 were non-academic (75\%). Twelve patients (40\%) had suffered a single or serial rib fracture. Incision length average was $2.5 \pm 1.3 \mathrm{~cm}$ (range, $1-5 \mathrm{~cm}$ ). Self-rated global outcome with the transthoracic procedure averaged $1.4 \pm 0.6$ (range, 1-3). One patient noted a moderate outcome, $10(33.3 \%)$ a good one, and $19(63.3 \%)$ an excellent overall clinical outcome. The morbidity was $10.8 \pm 15.4 \%$ (range, $0-59.5 \%$ ). Thirteen patients (43.3\%) had no morbidity related to their CTT (0-1 morbidity \%). In contrast, $46.7 \%$ of patients noted slight to moderate discomfort/pain related to the chest wound after a single CTT. A total of 11 patients $(36.7 \%)$ showed a morbidity greater than $10 \%$ (mean: $27.5 \pm 14 \%$; range: $11.6-59.5 \%$ ), which was defined as CPP. However, regarding the thoracic surgery, 6 patients out of these 11 rated their outcome as excellent, 4 as good, and only 1 patient, who had highest morbidity, judged his outcome as moderate. Nineteen patients $(63.3 \%)$ had a percentage morbidity of $0-10 \%$ (mean: $1.1 \pm 1.8 \%$, range: $0-5.4 \%$ ).

Signs of intercostal neuralgia were present in 5 patients (16.7\%). All patients that presented remaining pain at the chest wound made marks at the appropriate side of the chest wall on the antero-posterior sketch of the thoracic cage.

\section{Statistical analysis and intergroup differences}

As there is a lack of facts on the morbidity going with OTC, we deemed it appropriate to compare the results after large open thoracotomy for spinal surgery and minithoracotomies with chest tube insertion. Concerning self-rated clinical outcome and patients' academic educational level, there were no statistically significant intergroup differences. The prevalence of patients with signs of ICN was $16.7 \%$ in the CTT Group and $14.0 \%$ in the OTC Group, the difference yielded not statistical significance $(\mathrm{p}=0.75)$. According to the samples' nature (scoliosis versus trauma), age at index surgery and at follow-up was significantly higher in the CTT Group compared to the OTC Group $(\mathrm{p}<0.0001)$, and follow-up length was significantly shorter in the CTT Group ( $\mathrm{p}=0.02$ ).

For the OTC Group, statistical analysis revealed that there was no correlation between the self-rated global outcomes of the scoliosis surgery and the ArM ( $p=0.07$, $\mathrm{r}=0.028$ ). The ArM was correlative with age at index surgery $(\mathrm{p}=0.005, \mathrm{r}=0.42)$ and the self-rated global outcome was correlative with age at index and follow-up ( $p=0.006$, $\mathrm{r}=0.41 ; \mathrm{p}=0.03, \mathrm{r}=0.33$ ). Elderly patients that had VDS scoliosis correction for degenerative thoracolumbar scoliosis did worse in terms of ArM and self-rated global outcome than the younger patients, with most of them having thoracic AIS, although all patients noted to have an excellent or good clinical outcome.

For the CTT Group, the statistical analysis showed that neither age, follow-up length nor diagnosis (e.g., rib fractures) had a significant impact on the ArM. 
Factorial ANOVA with signs of ICN and therapy (CTT versus OTC) demonstrated that morbidity was significantly increased in both groups when patients had clinical evidence of ICN. Morbidity was about 6 times higher (ANOVA, $\mathrm{p}<0.0001$ ) in patients with signs of ICN (mean 29\%, 95\% CI: $18-39 \%$ ) compared to patients without it (means $5 \%$, 95\%CI: $2.4-7.5 \%$ ). The effect of ICN was still strong when analysis was calculated separately for the CTT and OTC Groups (2-factorial ANOVA, $\mathrm{p}<0.00001$, (Chart 1).

\section{DISCUSSION}

The current study is unique as it offers raw data on the approach-related morbidity following open thoracotomies using a detailed questionnaire that allows comparison.

In the senior authors' experience, in concert with many other experienced authors in open anterior deformity correction ${ }^{6,31,32}$, the morbidity that goes with an OTC is well tolerated by the patients. So, prior to initiation of the current study, the junior author hypothesized that following both a simple CTT and an OTC for major scoliosis surgery, a couple of patients would experience discomfort or even pain at the site of the chest wound, and that this incidence would be higher in the OTC Group. Astonishingly, the study revealed that patients' perception of morbidity was similar in both groups, with patients undergoing a simple CTT having even higher mean \%morbidity than those with an OTC (10.8 versus $7.0 \%)$. The percentage of patients that had a morbidity $>10 \%$ was also higher in the CTT Group than in the OTC Group (36.7 versus 18.6\%). Our findings contrast current trends suggesting that OTC for spinal surgery goes with a high ArM.

In comparison to VATS, the major disadvantages of OTC are claimed to be the large chest wall trauma with significant blood loss, poor cosmesis because the patients are left with a large scar, increased postoperative pain due to large chest wall incision and muscle dissection, necessity of rib resections, extensive intercostal wound spreading to gain sufficient exposure of the vertebral column which, in turn, compromises postoperative and long-term pulmonary and shoulder girdle function ${ }^{13-27}$. The increased postoperative pain is said to interfere with rapid rehabilitation and return to normal life $\mathrm{l}^{4,15,17,18,20,25}$. Cranial and caudal exposures through a single thoracotomy were judged limited with single OTC, ${ }^{10,22}$ the dissection of the latissimus dorsi was judged obligate ${ }^{18}$ and a double thoracotomy suggested to be often required for longer anterior fusions ${ }^{18,21}$. VATS is minimally invasive and said to result in faster recovery, shorter hospital stay and finally less time to functional re-

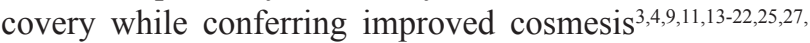
${ }^{33}$. However, proponents of VATS find it difficult to cite scientific articles that report homogenous comparative series shedding light on the assumption of less invasiveness of VATS in anterior spinal surgery compared to $\mathrm{OTC}^{6}$. There are few reports that compare the functional outcome after these two techniques $\mathrm{s}^{9,18,21,34}$. According to Arlet $^{12,28}$, the benefits of VATS procedures are not evident.

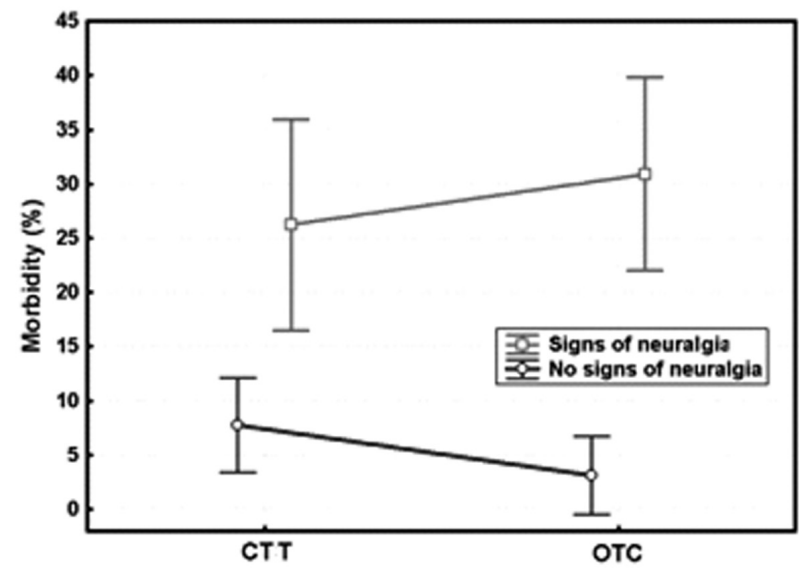

CHART 1

Morbidity (\%) following both a chest tube thoracotomy (CTT) and an open thoracotomy (OTC) plotted as a factor of intercostal neuralgia (ICN). Patients with clinical signs of ICN had significantly increased percentage morbidity in both the CTT and OTC-group $(p<0.0001)$.

It involves the learning process of an unfamiliar technique, specific skills, often the assistance of a thoracic surgeon, more operating room time, besides being more expensive than an OTC procedure, and a sufficient volume of patients is indicated to acquire enough expertise to accelerate ${ }^{9-11,27}$. In a recent review on instrumented VATS, the group of Arlet concluded that the claimed benefits of instrumented VATS for anterior scoliosis correction do not seem to be clearly demonstrated in literature, and the rate of associate complications seemed to be unacceptably high to its recommendation.

Currently, the use of VATS in spine surgery mainly includes the treatment of prolapsed thoracic disc disease, fracture management and anterior releases and fusion with or without instrumentation for scoliosis correction ${ }^{23}$. For levels 1 and 2 thoracoscopic surgeries, 3 to 5 portals are used $^{4,13,20,23,25,26}$, while 4 to 6 portals are necessary in longer fusions $^{4,9,12,28}$. Rib harvesting adds 1 to 2 skin incisions and another is added for lumbar extension ${ }^{4,10}$. Incisional lengths measure about 1.5 to $3 \mathrm{~cm}$ for the portals, resulting in a total incisional length of about $8-12 \mathrm{~cm}^{4,9,24,26}$. Concerning incisional length and cosmesis, no measure exists assessing its impact on patients' well-being. In the current study, none of the scoliosis patients with a mean incisional length of $25.5 \mathrm{~cm}$ had concerns regarding the scar and all patients noted a good or excellent self-rated global outcome joining similar long-term experiences ${ }^{6,31,32,35,36}$.

Regarding perioperative measures, the operative time is significantly extended using VATS compared to OTC for spinal surgeries ${ }^{9,10,12,22,23}$. The expected blood loss using VATS can be slightly smaller than with an OTC ${ }^{18,26}$ or equal ${ }^{9,25}$. Postoperative chest tube output can be lower using VATS ${ }^{9}$, similar ${ }^{16}$ or higher compared to $\mathrm{OTC}^{20,25}$. Minor complications directly attributed to VATS include pleural effusions indicating puncture or prolonged chest 
tube drainage (that might be due to the inability of suture closing the pleura), pneumothorax formation, and an increased rate of atelectasis and mucoid plug formation during collapsed lung surgery ${ }^{10,16,19,37-39}$. Serious complications previously reported include lung injuries, the development of tension pneumothorax, neurologic injury and serious arterial bleeding indicating urgent conversion to OTC $^{12,20,23,38,40-42}$.

The choice of the transthoracic access technique should not put a long-term cure at risk because of presumed shortterm benefits ${ }^{43}$, and whether VATS or OTC is used to gain access to the anterior spine, achieving a solid fusion is one of the main surgical purposes. Using VATS, this goal might be compounded in comparison to OTC ${ }^{12}$. Following anterior decompression, fusion and plating using VATS for the reconstruction of thoracolumbar fractures, Briem et al. ${ }^{37}$ observed that $65 \%$ of patients had complete fusion using iliac crest autografts, $25 \%$ had partial fusion and $10 \%$ had complete failure documented on fine computed tomography (CT scans). In contrast, fusion-rates in open anterior surgery for thoracolumbar burst fractures were reported with $93-100 \%{ }^{44-47}$. Picetti et al. ${ }^{10}$ reported an $80-\%$ fusion-rate following VATS for anterior instrumented scoliosis correction, the nonunions were referred to the use of Grafton. Newton et al. ${ }^{7}$ reported a 53-\% union rate in 15 scoliosis patients in a 5-year follow-up. In a series of 73 fractured patients submitted to VATS spinal procedures, kyphotic deformity reconstruction and grafting were showed to be difficult applying a VATS procedure and manipulation of the spinal segment to be realigned was considered better with OTC. In levels 1 to 2 anterior instrumented fusions using VATS for thoracolumbar fractures Khoo et al. ${ }^{11}$ reported a radiographic 1-year union-rate of $86 \%$. In another report ${ }^{48}$, the authors noted many cases with necrosis of instrumented thoracoscopically inserted bone grafts or lack of connection to the endplates. Early experience with anterior thoracic release and fusion using VATS caused the authors to opt for OTC that allows a more complete disc excision, grafting, shorter surgical time and morbidity which does not seem elevated ${ }^{12,49}$. In a biomechanical setup, Connolly et al..$^{50}$ observed that thoracoscopically instrumented thoracic corpectomies and strut-grafting did not have the same strength as reconstructions obtained via open procedure. In comparison to open discectomy, endplate and fusion bed preparation and grafting, the thoracoscopic fusion might be more difficult causing reduced fusion rates ${ }^{49,51}$. Schultheiss ${ }^{52}$ reported on 45 patients, merely fractures, subjected to instrumented VATS in 20 cases and mini-open thoracoscopically assisted anterior surgery with a mean incision length of $10 \mathrm{~cm}$ in the remainders. Fracture reconstruction was judged difficult using VATS, which indicates posterior transpedicular reduction and stabilization prior to anterior column reconstruction. In general, a small OTC was recommended. A review of literature by Reddi et al. ${ }^{12}$ including 299 patients submitted to instrumented VATs scoliosis correction concluded that the pseudoarthrosis rate was unacceptably high. Prospective trials with standard CT scans at follow-up are lacking that could might refute the assumption those fusion-rates are reduced using VATS.

Concerning postoperative pain, Picetti et al. ${ }^{10}$ noted that VATS scoliosis patients had discontinued the use of pain medication by 3.5 weeks. Although there was no comment on the characteristics of a Control Group, OTC scoliosis patients required pain medication for an average of 9.2 weeks. Data suggested that VATS reduces postoperative analgesic usage ${ }^{4}$. Beisse et al. ${ }^{15}$ compared administration of analgesics during the first 3 postoperative weeks among 30 patients submitted to VATS and 30 controls with OTC for levels 1 to 2 anterior-only or combined reconstructions of thoracolumbar injuries. Using a patient-controlled analgesic pump, VATS patients were reported to have less need for intravenous piritramid in comparison to a selected control OTC Group. Duration of postoperative oral analgesic usage was shorter in the VATS Group compared to the OTC Group. Whether intergroup differences existed regarding comorbidities, e.g. concomitant chest, pelvic, abdominal or multiple trauma or extended soft-tissue disruption and pain that frequently go with $\mathrm{AO}$ type $\mathrm{B}$ or $\mathrm{C}$ injuries, was not reported $;{ }^{15}$ differences in the main covariables would explain the $15-\%$ difference in return to work rate. ${ }^{11}$ The studies of Landrenau et al..$^{53,54}$ are frequently cited. These author ${ }^{53}$ observed that patients experienced significantly less pain on the $1^{\text {st }}$ and $2^{\text {nd }}$ days after VATS in comparison to OTC. Unfortunately, the study found difficulty in the comparison of intrathoracic pathologies. Only 7 out of 81 patients undergoing VATS had a lobectomy compared to 38 of 57 OTC cases. Forty-three of the 57 OTC patients suffered from a malignant disease compared to 33 of the 81 VATS patients. In a prospective, randomized study on VATS for benign intrathoracic pathologies, Forster et al. ${ }^{43}$ observed borderline significance for differences in pain for the $2^{\text {nd }}$ but not for the $4^{\text {th }}$ postoperative day. The authors emphasized that the benefits concerning surgical trauma and quality of life after the thoracoscopic access in comparison to an OTC were much less pronounced than expected. The benefits of the VATS approach seemed to be restricted to the intraoperative and immediate postoperative period and not extending beyond the first 2 or 3 postoperative days.

Perioperative and long-term pulmonary function was used a an outcome anchor comparing VATS and OTC in spinal procedures. ${ }^{9}$ Notably, Lenke et al. ${ }^{34}$ identified only minimal but no significant differences in 2-year pulmonary function after VATS or OTC for anterior releases. Kishan et al. ${ }^{21}$ reported 2-year results of 36 patients submitted to VATS for anterior instrumented scoliosis correction and fusion compared to 28 patients that had OTC without thoracoplasty and 43 that had OTC with thoracoplasty. Concerning pulmonary function testing, most differences between the VATS and the OTC-thoracoplasty Group were significant due to the associated thoracoplasty. Faro et al. ${ }^{18}$ 
compared instrumented anterior scoliosis correction using VATS or OTC. Remarkably, $43 \%$ of patients in the OTC Group had double thoracotomy and 35\% had thoracoplasties. Even though the OTC Group had obviously the more extensive surgery, there was only a trend that the percentage predicted forced vital capacity was reduced compared to the VATS Group. The authors ${ }^{18}$ concluded that both approaches, VATS and OTC, result in a temporary postoperative decrease in pulmonary function and the degree in which thoracoscopy mitigated this decline was considered modest at best. Izatt et al. ${ }^{55}$ identified significant correlations between both pulmonary function tests and the Cobb correction percentage and number of levels instrumented. Comparing their results to a historical control OTC Group, ${ }^{56}$ the analysis showed similar preoperative and 2-year postoperative values between the VATS and OTC Group. According to the authors, slightly better pulmonary function tests might not originate from using VATS but rather resembling an effect of the scoliosis correction and recovery from surgery itself. ${ }^{55}$ Kim et al. ${ }^{57}$ showed, in 55 patients treated with open thoraco-abdominal approaches for scoliosis correction, that forced vital capacity absolute value was $2 \%$ lower at 2 -year follow-up, resembling a mean of $60 \mathrm{~mL}$.

The alleged benefits of VATS concerning postoperative upper extremity and shoulder girdle function were not clear. Newton et al. ${ }^{9}$ did not observe significant differences between 38 VATS patients and 68 OTC patients after anterior instrumented scoliosis correction for either flexion or abduction measures, including motion and strength, at hospital discharge and at 6-week follow-up 9 . A recent study of the same group ${ }^{58}$ showed that after 1 year, both VATS and OTC patients shoulder abduction strength and range of motion were back to baseline without showing significant intergroup differences.

Finally, significant complications of OTC are said to be ICN and $\mathrm{CPP}^{11}$. Therefore, we evaluated the mid- to long-term morbidity following a CTT and OTC with special focus on ICN and CPP. According to our definition (>10\% morbidity), $35.5 \%$ had CPP following a simple chest tube thoracotomy while $18.6 \%$ had a CPP following large open transthoracic scoliosis surgery. Only one patient in the OTC and CTT Group demanded analgesics for pain related to the chest wound. Retrospectively, our arbitrarily chosen definition of CPP ( $>10 \%$ morbidity) seemed to be rather strong, and according to the 2 patients presenting with ArM, a threshold of $>50 \%$ would be sensible when using the proposed questionnaire in future studies. In OTC for thoracic pathologies, Dajczman et al..$^{59}$ identified CPP in $73 \%$ of patients at 2 year, in $54 \%$ at 3 -year and in $30 \%$ at 5 -year follow-up. In cardiothoracic surgeries, the incidence of CPP was reported to range between 11 and $80 \%{ }^{60}$, while Rogers et al. ${ }^{61}$ reviewed that CPP was present in approximately $50 \%$ being severe and disabling in $5 \%$. Comparative studies in thoracic surgery have shown that there is no difference in the occurrence of CPP following VATS or OTC ${ }^{60,61}$. In a long-term follow-up with 144 patients undergoing VATS procedures for benign thoracic diseases, Hutter et al. ${ }^{62}$ demonstrated that sequels were present in $32 \%$ of patients in a 32 -month follow-up and in $13 \%$ in a 123 -month follow-up ${ }^{63}$. The study showed a significant follow-up-dependant drop in the prevalence of sequels following VATS. Recently, a German group ${ }^{39}$ presented the results of VATS for anterior reconstruction in 60 spinal fractures. Assessment included a physicians' judgement on the perceived ArM in four grades (grade 4 resembles disabling pain). ArM outreached a mean of 2.5 grades in the postoperative period with a down slope towards grade 1 at 12 months and finally the mean of 0.5 at an 18-month follow-up.

Grewal's study ${ }^{64}$ directly compared outcome in anterior scoliosis correction using OTC and VTS, and noticed a significantly longer surgical time and blood loss with VATS but no obvious benefit. Different studies comparing OTC and VATS suffer from rather small OTC Control Groups and heterogeneous samples concerning number of patients, percentage of patients with neuromuscular disorders or kyphotic deformities, magnitude of scoliotic curves treated, performance of rib resections, incidence of revision surgeries, added thoracoplasties or comparing VATS with patients that have double or single thoracotomies $9,16,18,20,22,24-26,34$.

Comparisons between VATS and OTC for spinal pathologies remain difficult. Therefore, the authors applied an easy-to-understand questionnaire that allowed for numerical comparison of morbidity variables. Morbidity of CTT was $10.8 \%$ on average and $7.0 \%$ after OTC. Notably, aside a local 'discomfort' or 'intermittent slight pain' in patients with any morbidity, $>0 \%$ our survey showed that the most important cause for an increased discomfort and pain at the site of a former CTT or OTC is the presence of intercostal nerve damage (Chart 1). Our statistical analysis revealed a strong correlation between increased ArM and presence of ICN. These objective data are well compared to previous clinical observations attributing CPP to posttraumatic intercostal neuroma and nerve damage ${ }^{59}$. In terms of clinical description, McAffee et al. ${ }^{38}$ reported the incidence of ICN after spinal VATS procedures as an $8 \%$ rate. In Assaker's ${ }^{65}$ study, ICN was observed in $6.8 \%$ of patients. Notably, in our series, we identified the incidence of ICN as $16.1 \%$ in the CCT Group compared to $13 \%$ in the OTC Group. Findings indicate that the performance of any transthoracic surgical manipulation is a risk factor for ICN and for a subsequent CPP rather than the incision length, anatomical dissection or type of thoracotomy. In the current study, we illustrated that the incidence of CPP and ICN was similar following OTC and CTT.

The performed CTT has characteristics similar to a working portal in spinal VATS procedures where several small transthoracic approaches are performed to gain access for the instruments needed. Accordingly, ICN has been an early concern in VATS ${ }^{33}$, but surprisingly not in most series reporting the results of VATS for spinal 
procedures $^{64}$. A review of literature ${ }^{60}$ concluded that the minimally invasive approach offered by VATS had not the favourable impact on pain ${ }^{60}$ that many anticipated from general and cardiothoracic surgery perspectives ${ }^{53,54,66}$. The reasons for resulting ICN and CPP in the VATS patients were suggested to be referred to intercostal nerve damage and chest wall trauma from trocar insertion ${ }^{60,65}$. We suggest the same injury mechanism in CTT and OTC. Intercostal nerve dysfunction may result from incision and direct injury, trocar placement, retraction or periostal sutures in the OTC and CTT patient.

The fact that we observed a low ArM after the thoracotomies might be due to distinct training, frequency of performing OTC or technical details. Although Rogers et al. ${ }^{61}$ did not identify differences following OTC using technical modifications (muscle-sparing versus muscle-cutting approach; rib resection versus no rib resection), there are actually a number of modifiable technical aspects that affect postoperative pain including the type of incision, soft tissue handling, nerve root manipulation and rib approximation at closure ${ }^{15,60,67}$. In addition, when perioperative pain is managed aggressively, the post-thoracotomy pain can be significantly decreased and chronification, avoided ${ }^{60}$.

The open transthoracic approach to the spine was said to be more invasive because of the larger incisions, yet the size of the scar certainly does not tell the true story ${ }^{21}$. We scrutinize whether or not the sum effect of several transthoracic incisional approaches equals that of a single large cut. Our results show that, with a single transthoracic approach, e.g., as in CTT, the approach-related morbidity and incidence of ICN are in the ranges of an OTC.

The strength of our study includes that the severity and long-term morbidity of a large, open transthoracic spinal approach were well characterized by comparing morbidity variables of OTC and of CTT. The questionnaire showed to be effective to directly compare the thoracic approachrelated morbidity following a CTT and an OTC. However, the authors have to emphasize that, although a few patients in the scoliosis group noted some morbidity at the chest wall, all scoliosis patients noted to have an either excellent or good self-rated global outcome with the scoliosis surgery. With the exception of one patient with correction of an adult degenerative scoliosis, any discomfort described at the thoracotomy side was negligible.

\section{LIMITATIONS}

Demographic data of both groups did not match in regard to age, gender ratio and follow-up length, and we did not yield for matched pairs. We thought that with a long-term follow-up $>3-5$ years in the CTT Group there would be no detectable morbidity at all and, thus, we decided to use a rather short- to mid-term follow-up for the CTT Group. Concerning gender, working with AIS patients will always result in a female predominance. Nonetheless, follow-up length and gender had no impact on morbidity values or the incidence of ICN, and the pre- or absence of rib fractures did not have any effect on the morbidity or incidence of ICN. We are aware of proposing a non-validated questionnaire, but the authors judge it difficult to validate such outcome measures as normal patients usually do not have any chest wall mediated pain. The current questionnaire strongly lends on the VAS-Spine-Score, a validated outcome instrument ${ }^{68}$. Analysis of the re-test reliability on an outpatient clinic basis was not possible in the current series. We do not judge this a significant drawback because it would not change the main results concerning comparison of OTC to CTT.

\section{FINAL CONSIDERATIONS}

Proponents of VATS argue that anterior thoracic spine surgery can be performed with the same accuracy and completeness as it is possible by the conventional OTC, but through much smaller skin portion and muscle incisions causing less $\mathrm{ArM}^{2}$. Large clinical studies in concert with our experiences of instrumented anterior scoliosis surgeries using open anterior thoracotomies ${ }^{31,32,6}$ do not experience ArM as a clinical problem. The current review showed that the claimed superiority of VATS to avoid approach-related morbidity compared to open anterior spinal surgery has not been proven so far.

\section{REFERENCES}

1. Betz RR, Harms J, Clements DH 3rd, Lenke LG, Low TG, Shufflebarger HL, et al. Comparison of anterior and posterior instrumentation for correction of adolescent thoracic idiopathic scoliosis. Spine (Phila Pa 1976). 1999;24(3):225-39.

2. Hempfing A, Ferraris L, Koller H, Rump J, Metz-Stavenhagen P. Is anterior release effective to increase flexibility in idiopathic thoracic scoliosis? Assessment by traction films. Eur Spine J. 2007;16(4):515-20.
3. Kim HS, Lee CS, Jeon BH, Park JO. Sagittal plane analysis of adolescent idiopathic scoliosis after VATS (video-assisted thoracoscopic surgery) anterior instrumentations. Yonsei Med J. 2007;48(1):90-6.

4. Norton RP, Patel D, Kurd MF, Picetti GD, Vaccaro AR. The use of thoracoscopy in the management of adolescent idiopathic scoliosis. Spine (Phila Pa 1976). 2007;32(24):2777-85.

5. Rosenthal D. Endoscopic approaches to the thoracic spine. Eur Spine J. 2000;9 Suppl 1:S8-16.
6. Lubicky JP. Point of view. Spine (Phila $\mathrm{Pa}$ 1976). 2008;33(20):2236.

7. Newton PO, Upasani VV, Lhamby JT, Pawelek J, Bastrom T. Five-year follow-up of adolescent idiopathic scoliosis patients surgically treated with thoracoscopic anterior instrumentation. Presented at SRS $42^{\text {nd }}$ annual meeting. Edingburgh, Scottland, 2007. Paper 116. [Internet] [cited 2010 Apr 19]. Available from: http://www.srs.org/professionals/ meetings/am07/papers.pdf 
8. Cheung KM, Lu DS, Zhang H, Luk KD. In-vivo demonstration of the effectiveness of thoracoscopic anterior release using the fulcrum-bending radiograph: a report of five cases. Eur Spine J. 2006;15 Suppl 5:578-82.

9. Newton PO, Marks M, Faro F, Betz R, Clements D, Haher T, et al. Use of video-assisted thoracoscopic surgery to reduce perioperative morbidity in scoliosis surgery. Spine (Phila $\mathrm{Pa}$ 1976). 2003;28(20):S249-54.

10.Picetti GD 3rd, Pang D, Beuff HU. Thoracoscopic techniques for the treatment of scoliosis: early results in procedure development. Neurosurgery. 2002;51(4):978-84; discussion 984.

11. Khoo LT, Beisse R, Potuslki M. Thoracoscopic-assisted treatment of thoracic and lumbar fractures: a series of 371 consecutive cases. Neurosurgery. 2002;51(5 Suppl):S104-17.

12.Reddi V, Clarke DV Jr, Arlet V. Anterior thoracoscopic instrumentation in adolescent idiopathic scoliosis: a systematic review. Spine (Phila $\mathrm{Pa}$ 1976). 2008;33(18):1986-94.

13.Al-Sayyad MJ, Crawford AH, Wolf RK. Video-assisted thoracoscopic surgery: the Cincinnati experience. Clin Orthop Rel Res. 2005;(434): 61-70.

14.Al-Sayyad MJ, Crawford AH, Wolf RK. Early experiences with videoassisted thoracoscopic surgery: our first 70 cases. Spine (Phila Pa 1976). 2004;29(17):1945-51; discussion 1952.

15.Beisse R, Potulski M, Bühren V. Thorakoskopisch gesteuerte ventrale Plattenspondylodese bei Frakturen der Brust-und Lendenwirbelsäule. Operat Orthop Traumatol. 1999;11(1):54-59. German.

16.Bomback DA, Charles G, Widmann R, Boachie-Adjei O. Video-assisted thoracoscopic surgery compared with thoracotomy: early and late followup of radiographical and functional outcome. Spine J. 2007;7(4):399-405.

17.Burd TA, Pawelek L, Lenke LG. Upper extremity functional assessment after anterior spinal fusion via thoracotomy for adolescent idiopathic scoliosis: prospective study of twentyfive patient. Spine (Phila Pa 1976). 2002;27(1):65-71.
18.Faro FD, Marks MC, Newton PO, Blanke K, Lenke LG. Perioperative changes in pulmonary function after anterior scoliosis instrumentation: thoracoscopic versus open approaches. Spine (Phila Pa 1976). 2005;30(9):1058-63.

19. Herrera-Soto JA, Parikh SN, AlSayyad MJ, Crawford AH. Experience with combined video-assisted thoracoscopic surgery (VATS) anterior spinal release and posterior spinal fusion in Scheuermann's kyphosis. Spine (Phila Pa 1976). 2005;30(19):2176-81.

20.Huang EY, Acosta JM, Gardocki RJ, Danielson PD, Skaggs DL, Reynolds RA, et al. Thoracoscopic anterior spinal release and fusion: evolution of a faster, improved approach. J Pediatr Surg. 2002;37(12):1732-5.

21.Kishan S, Bastrom T, Betz RR, Lenke LG, Lowe TG, Clements $\mathrm{D}$, et al. Thoracoscopic scoliosis surgery affects pulmonary function less than thoracotomy at 2 years postsurgery. Spine (Phila Pa 1976). 2007;32(4):453-8.

22.Levin R, Matusz D, Hasharoni A, Scharf C, Lonner B, Errico T. Mini-open thoracoscopically assisted thoracotomy versus video-assisted thoracoscopic surgery for anterior release in thoracic scoliosis and kyphosis: a comparison of operative and radiographic results. Spine J. 2005;5(6):632-8.

23.Liu GK, Kit WH. Video assisted thoracoscopic surgery for spinal conditions. Neurol India. 2005;53(4):489-98.

24.Lonner BS, Kondrachov D, Siddiqi F, Hayes V, Scharf C. Thoracoscopic spinal fusion compared with posterior spinal fusion for the treatment of thoracic adolescent idiopathic scoliosis. J Bone Joint Surg Am. 2006;88(5):1022-34.

25.Reilly CW, Slobogean GP, Choit RL. The efficacy of video-assisted thoracoscopic surgery for anterior release and fusion in the management of pediatric spinal deformities. Can J Surg. 2006;49(5):341-6.

26.Son-Hing JP, Blakemore LC, PoeKochert C, Thompson GH. Videoassisted thoracoscopic surgery in idiopathic scoliosis: evaluation of the learning curve. Spine (Phila Pa 1976). 2007;32(6):703-7.
27. Thongtrangan I, Le H, Park J, Kim DH. Minimally invasive spinal surgery: a historical perspective. Neurosurg Focus. 2004;16(1):E13.

28. Arlet V. Anterior thoracoscopic spine release in deformity surgery: a metaanalysis and review. Eur Spine J. 2000;9 Suppl 1:S17-23.

29.Merskey H. Classification of chronic pain. Descriptions of chronic pain syndromes and definitions of pain terms. Prepared by the International Association for the Study of Pain, Subcommittee on Taxonomy. Pain Suppl. 1986;3:S1-226.

30.von Strempel A. Die vordere Wirbelsäulenbegradigung mit der ventralen Derotationsspondylodese (VDS) nach Zielke. Operat Orthop Traumatol. 1995;7:143-53.

31.Kovac V. What is objective in anterior versus posterior instrumentation for AIS. A 25 years experience. Spineweek. Geneva, 2008: Poster \#139.

32.Kusakabe T, Gaines RW. Results after short segment bone-on-bone instrumentation for single curve adolescent idiopathic scoliosis after mean follow-up of 6 years. IMAST. Hongkong, 2008. Paper 128. [Internet] [cited 2010 Apr 19]. Available from: http:/www.srs.org/ imast/past/08CompleteProgramBook_ FINAL.pdf

33. Mack MJ, Regan JJ, McAfee PC, Picetti G, Ben-Yishay A, Acuff TE. Video-assisted thoracic surgery for the anterior approach to the thoracic spine. Ann Thorac Surg.1995;59(5):1100-6.

34.Lenke LG, Newton PO, Marks MC, Blanke KM, Sides B, Kim YJ, et al. Prospective pulmonary function comparison of open versus endoscopic anterior fusion combined with posterior fusion in adolescent idiopathic scoliosis. Spine (Phila Pa 1976). 2004;29(18):2055-60.

35.Iwasaki A, Hamatake D, Shirakusa T. Biosorbable poly-L-lactide ribconnecting pins may reduce acute pain after thoracotomy. Thorac Cardiovasc Surg. 2004;52(1):49-53.

36.Wang Y, Fei Q, Qiu G, Lee CI, Shen J, Zhang J, et al. Anterior spinal fusion versus posterior spinal fusion for moderate lumbar/thoracolumbar adolescent idiopathic scoliosis: a prospective study. Spine (Phila $\mathrm{Pa}$ 1976). 2008;33(20):2166-72. 
37.Briem D, Windolf J, Lehmann W, Begemann PG, Meenen NM, Rueger $\mathrm{JM}$, et al. [Bone grafts endoscopically applied to the spine Ergebnisse der anterioren Fusion und therapeutische Konsequenzen]. Unfallchirurg. 2004;107(12):1152-61. German.

38.McAfee PC, Regan JR, Zdeblick T, Zuckerman J, Picetti GD 3rd, Heim S, et al. The incidence of complications in endoscopic anterior thoracolumbar spinal reconstructive surgery.

A prospective multicenter study comprising the first 100 consecutive cases. Spine (Phila Pa 1976). 1995;20(14):1624-32.

39.Merkel P, Hauck S, Zentz F, Bühren $\mathrm{V}$, Beisse R. [Spinal column injuries in sport: treatment strategies and clinical results]. Unfallchirurg. 2008;111(9):711-8. German.

40.Hanley E, Green NE, Spengler DM; American Orthopaedic Association. An AOA critical issue. Less invasive procedures in spine surgery. J Bone Joint Surg Am. 2003;85-A(5):956-61.

41.Holz R, Schultz C, Mayr E. Conus Cauda Syndrom nach ventraler Spondylodese (in german). German Congress for orthopedic and traumatology. Berlin, 2008. [Internet] [cited 2010 Apr 19]. Available from: http://www.p-s-m.org/static/de/ meetings/dkou2008/08dkou740.shtml

42.Roush TF, Crawford AH, Berlin RE, Wolf RK. Tension pneumothorax as a complication of video-assisted thorascopic surgery for anterior correction of idiopathic scoliosis in an adolescent female. Spine (Phila Pa 1976). 2001;26(4):448-50.

43.Förster R, Storck M, Schäfer JR, Hönig E, Lang G, Liewald F. Thoracoscopy versus thoracotomy: a prospective comparison of trauma and quality of life. Langenbecks Arch Surg. 2002;387(1):32-6.

44.Hitchon PW, Torner J, Eichholz KM, Beeler SN. Comparison of anterolateral and posterior approaches in the management of thoracolumbar burst fractures. J Neurosurg Spine. 2006;5(2):117-25.

45.Kaneda K, Taneichi H, Abumi K, Hashimoto T, Satoh S, Fujiya M. Anterior decompression and stabilization with the Kaneda device for thoracolumbar burst fractures associated with neurological deficits. J Bone Joint Surg Am. 1997;79(1): 69-83.
46.Korovessis P, Baikousis A, Zacharatos S, Petsinis G, Koureas G, Iliopoulos P. Combined anterior plus posterior stabilization versus posterior shortsegment instrumentation and fusion for mid-lumbar (L2-L4) burst fractures. Spine (Phila Pa 1976). 2006;31(8):859-68.

47. Sasso RC, Renkens K, Hanson D, Reilly T, McGuire RA Jr, Best NM. Unstable thoracolumbar burst fractures: anterior-only versus shortsegment posterior fixation. J Spinal Disord Tech. 2005;19(4):242-8.

48.Hauck S, Berger A, Gonschorek $\mathrm{O}$, Bühren V. First results with a trabecular metal - Cage for monosegmental fusions in thoracoscopic fusion technique in unstable fractures of the thoracolumbar spine. Eur Spine J. 2008;17(11):1540-633. [Presented at Deutscher Wirbelsäulenkongress Nov.08/Ulm].

49.Papin P, Arlet V, Marchesi D, Laberge JM, Aebi M. [Treatment of scoliosis in the adolescent by anterior release and vertebral arthrodesis under thoracoscopy. Preliminary results]. Rev Chir Orthop Reparatrice Appar Mot. 1998;84(3):231-8. French.

50.Connolly PJ, Clem MF, Kolata R, Ordway N, Zheng Y, Yuan H. Videoassisted thoracic corpectomy and spinal reconstruction: a biomechanical analysis of open versus endoscopic technique. J Spinal Disord. 1996;9(6):453-9.

51. Sucato DJ. Thoracoscopic anterior instrumentation and fusion for idiopathic scoliosis. J Am Acad Orthop Surg. 2003;11(4):221-7. Review.

52.Schultheiss M, Hartwig E, Kinzl L, Claes L, Wilke HJ. Thoracolumbar fracture stabilization: comparative biomechanical evaluation of a new video-assisted implantable system. Eur Spine J. 2004;13(2):93-100.

53.Landreneau RJ, Hazelrigg SR, Mack MJ, Dowling RD, Burke D, Gavlick J, et al. Postoperative pain-related morbidity: video-assisted thoracic surgery versus thoracotomy. Ann Thorac Surg. 1993;56(6):1285-9.

54.Landreneau RJ, Mack MJ, Hazelrigg SR, Naunheim K, Dowling RD, Ritter P, et al. Prevalence of chronic pain after pulmonary resection by thoracotomy or video-assisted thoracic surgery. J Thorac Cardiovasc Surg. 1994;107(4):1079-85; discussion 1085-6. Comment in: J Thorac Cardiovasc Surg. 1995;109(6):1255-6.
55.Izatt MT, Harvey JR, Adam CJ, Fender D, Labrom RD, Askin GN. Recovery of pulmonary function following endoscopic anterior scoliosis correction: evaluation at 3, 6, 12, and 24 months after surgery. Spine (Phila Pa 1976). 2006;31(21):2469-77.

56. Graham EJ, Lenke LG, Lowe TG, Betz RR, Bridwell KH, Kong $\mathrm{Y}$, et al. Prospective pulmonary function evaluation following open thoracotomy for anterior spinal fusion in adolescent idiopathic scoliosis. Spine (Phila Pa 1976). 2000;25(18):2319-25.

57.Kim YJ, Lenke LG, Bridwell KH, Cheh G, Sides B, Whorton J. Prospective pulmonary function comparison of anterior spinal fusion in adolescent idiopathic scoliosis: thoracotomy versus thoracoabdominal approach. Spine (Phila Pa 1976). 2008;33(10):1055-60.

58.Ritzman TF, Upasani VV, Pawalek JB, Betz RR, Newtn PO. Return to shoulder girdle function after anterior versus posterior adolescent idiopathic scoliosis surgery. Spine (Phila Pa 1976). 2008;33(20):2228-35.

59.Dajczman E, Gordon A, Kreisman H, Wolkove N. Long-term postthoracotomy pain. Chest. 1991;99(2):270-4.

60.Gottschalk A, Cohen SP, Yang S, Ochroch EA. Preventing and treating pain after thoracic surgery. Anesthesiology. 2006;104(3):594-600.

61.Rogers ML, Duffy JP. Surgical aspects of chronic post-thoracotomy pain. Eur J Cardiothoracic Surg. 2000;18(6):711-6.

62.Hutter J, Miller K, Moritz E. Chronic sequels after thoracoscopic procedures for benign diseases. Eur J Cardiothorac Surg. 2000;17(6):687-90.

63.Hutter J, Reich-Weinberger S, Hitzl W, Stein HJ. Sequels 10 years after thoracoscopic procedures for benign disease. Eur J Cardiothorac Surg. 2007;32(3):409-11.

64.Grewal H, Betz RR, D’Andrea LP, Clements DH, Porter ST. A prospective comparison of thoracoscopic vs open anterior instrumentation and spinal fusion for idiopathic thoracic scoliosis in children. J Pediatr Surg. 2005;40(1):153-6; discussion 156-7.

65.Assaker R. Minimal access spinal technologies: state-of-the-art, indications, and techniques. Joint Bone Spine. 2004;71(6):459-69. 
66.Bertrand PC, Regnard JF, Spaggiari L, Levi JF, Magdeleinat P, Guibert L, et al. Immediate and long-term results after surgical treatment of primary spontaneous pneumothorax by VATS Ann Thorac Surg. 1996;61(6):1641-5. 67.Cerfolio RJ, Price TN, Bryant AS, Sale Bass C, Bartolucci AA. Intracostal sutures decrease the pain of thoracotomy. Ann Thorac Surg. 2003;76(2):407-11; discussion 4112. Comment in: Ann Thorac Surg. 2005;79(2):750; author reply 750 .
68.Knop C, Oeser M, Bastian L, Lange U, Zdichavsky M, Blauth M. [Development and validation of the Visual Analogue Scale (VAS) Spine Score]. Unfallchirurg. 2001;104(6):488-97. German.

\author{
Correspondência \\ Luis Ferraris \\ German Scoliosis Center Bad Wildungen \\ Werner-Wicker-Klinik \\ Im Kreuzfeld 7 \\ D-34517 Bad Wildungen
}

